\title{
The influence of melatonin on carbohydrate metabolism in muscles of alloxan diabetic rats
}

\author{
I.M. Yaremii, O.Yu. Kushnir, V.I. Shvets, I.R. Yanchii ${ }^{1}$, N.V. Shvets \\ Higher Education Institution in Ukraine «Bukovinian State Medical University», Chernivtsi; \\ ${ }^{1}$ V.P. Komisarenko Institute of Endocrinology and Metabolism of NAMS Ukraine, Kyiv; \\ e-mail:kushnir@bsmu.edu.ua
}

\begin{abstract}
The aim of this study was to determine the influence of melatonin on basal level of glucose in the blood $(B G)$, glycogen content (GC), activities of glucose-6-phosphate dehydrogenase (G6PD), pyruvate kinase $(P K)$ and lactate dehydrogenase $(L D H)$ in muscles of alloxan diabetic rats under conditions of different photoperiod (artificial equinox, constant darkness and constant light). In the DM rats the LDH activity increased on average by $61 \%$, whereas the GC and the activities of $P K$ and G6PD decreased on average by 37, 53 and $40 \%$ respectively compared with control values. All of these changes were not dependent on the light conditions. The BG level of the IGT rats didn't reliably differ from the control, however, the LDH and the G6PD activities were respectively higher on average by 24 and $49 \%$, except rats under the constant light conditions whose G6PD activity was lower by 48\%. A melatonin administration (14 daily injections of $10 \mathrm{mg} / \mathrm{kg}$ ) led to an improvement of the carbohydrate metabolism: the BG level, the $G C$, the activities of $P K$ and $L D H$ were normalized, while the G6PG activity was increased by an average of $32 \%$. The influence of melatonin was more prominent in the IGT rats under the constant light conditions.

Key words: melatonin; alloxan diabetes; carbohydrate metabolism; muscles; rats.
\end{abstract}

\section{INTRODUCTION}

Melatonin (N-acetyl-5-methoxytryptamine) is an indoleamine with potent multifunctional biological and pharmacological effects, both receptor dependent and receptor-independent, including antioxidant, anticancer, antitumor, anti-inflammatory, anti-aging, antidiabetic, antiviral and neuroprotective activities. Melatonin mitigates tissue injury via modification of abnormalities in redox status and other biochemical markers. At the molecular level, a biological and pharmacological activity of melatonin is attributed to nuclear factor-карра beta (NF-KB) inhibition, c-Fos overexpression and matrix metalloproteinases-3 (MMP-3) down-regulation, which are regulators of pro-inflammatory and pro-fibrotic cytokines. There are numerous scientific reports on melatonin therapeutic potential in treatment of asthma, infection respiratory diseases, chronic obstructive pulmonary disease, lung cancer, pleural cavity diseases and vascular pulmonary disease [1].

Circadian disruption and obesity synergize to predispose Type 2 diabetes (T2DM) development, signifying that therapeutic targeting of both circadian and metabolic dysfunctions should be considered as a potential treatment approach. Importantly, the combination of melatonin and metformin had synergistic action to modify progression of metabolic dysfunction in circadian disruption obesity rats through improved adiposity, circadian activity, insulin sensitivity and islet cell failure. At the same time, melatonin treatment alone improved circadian activity rhythms, attenuated induction of beta cell failure and enhanced glucose tolerance [2].

It was known that changes in the lightdark cycle in vivo entrain the phase of islet clock transcriptional oscillations, whereas prolonged exposure (10 weeks) to light at night disrupts islet circadian clock function

(C) I.M. Yaremii, O.Yu. Kushnir, V.I. Shvets, I.R. Yanchii, N.V. Shvets 
through impairment in the amplitude, phase, and inter islet synchrony of clock transcriptional oscillations. Also, it was reported that light at night exposure leads to diminished glucosestimulated insulin secretion due to a decrease in insulin secretory pulse mass. This study identifies potential mechanisms by which disturbances in circadian rhythms, common to modern life, can predispose to the islet failure in T2DM [3]. The clock disruption leads to transcriptome-wide alterations in the expression of islet genes involved in growth, survival and synaptic vesicle assembly. Notably, conditional ablation of the pancreatic clock causes diabetes mellitus (DM) due to defective beta-cell function at the very latest stage of stimulus-secretion coupling. These results demonstrate a role for the beta-cell clock in coordinating insulin secretion with the sleep-wake cycle and reveal that ablation of the pancreatic clock can trigger the DM onset [4].

It was shown that 14-day introduction of melatonin to alloxan diabetic rats under conditions of constant darkness led to a decrease in the basal glycaemia level as well as a stabilization in the indices of the antioxidant defense disturbed by an absolute deficit of insulin [5].

Melatonin is a highly efficient scavenger of reactive oxygen species and it also exhibits beneficial anti-inflammatory and anti-ageing effects. Also, melatonin exhibits marked antioxidant and anti-ageing effects in skeletal muscles, similar to those of alpha-lipoic acid even if given in much lower doses [6]. But the relationship between the effects of melatonin on glycolysis and antioxidant protection in muscle of alloxan diabetic rats is poorly understood.

The aim of this study was to determine the influence of melatonin on basal glucose (BG) level in the blood, glycogen content (GC), glucose-6-phosphate dehydrogenase [EC 1.1.1.49] (G6PD), pyruvate kinase [EC 2.7.1.40] (PK) and lactate dehydrogenase [EC 1.1.1.27] (LDH) activities in muscles of alloxan diabetic rats under conditions of different photoperiod.

\section{METHODS}

The research was performed in compliance with the Rules of the work using experimental animals (1977) and the Council of Europe Convention on the Protection of Vertebrate Animals used in experiments and other scientific purposes (18 March 1986). The experiments were carried out on 158 sexually mature male albino rats with the body mass $0.18-0.20 \mathrm{~kg}$. Alloxan diabetes was evoked via intraperitoneal injection with a $5 \%$ solution of alloxan monohydrate in a dose of $170 \mathrm{mg} / \mathrm{kg}$ of body weight. The animals were divided into 3 groups: 1) rats under artificial equinox (Light: Darkness $=12: 12$, LD); 2) rats under constant dark (L:D = 0:24, DD); 3 ) rats under constant light (L:D = 24:0, LL). In each group there were 5 subgroups: 1) control group; 2) group with $\mathrm{DM}$ (BG level $\geq 8.0 \mathrm{mmol} / \mathrm{l})$; 3 ) alloxan diabetic animals with overt diabetes which were injected with melatonin; 4) alloxan diabetic rats with impaired glucose tolerance (IGT) $($ BG level $\leq 6.9 \mathrm{mmol} / \mathrm{l}) ; 5)$ alloxan diabetic animals with IGT which were injected with melatonin. Melatonin ("Sigma", USA) was injected intraperitoneally in a dose of $10 \mathrm{mg}$ / $\mathrm{kg}$ of body weight at 8 a.m. daily over 14 days starting with a 5 th 24 -h period after the alloxan injection. The blood was taken from the tail vein to evaluate the BG level using "OneTouchUltra" ("LifeScan", USA). The rats were sacrificed at the 19th day of the experiments in accordance with the ethical treatment of animals. To precipitate glycogen rectus femoris muscle tissue was split with $30 \% \mathrm{KOH}$ solution followed by the addition of ethanol and cooling. Then, glycogen was hydrolyzed with sulfuric acid to glucose, the level of which was used as an indicator of the GC. To determine the enzymes activities by standard methods [7] muscle tissue was quickly removed, rinsed in saline, blotted, weighed and homogenized. Then the homogenate $(5 \%$ in ice-cold $0.25 \mathrm{mM}$ trisHCl-buffer) was ultracentrifugated (10 $\mathrm{min}$ at $1500 \mathrm{r} / \mathrm{min}$ ) and the supernatant was used for measurements. 
Statistical analysis was performed using Statistica 10 (StatSoft Inc). Prior to analysis, Shapiro-Wilk test was used to assess the normality of the group data. According to the criterion, the samples distributions differed from normal distribution. Given these, use of the Mann-Whitney test was considered sufficient for valid conclusions to be made. Differences were considered to be statistically significant if $\mathrm{P} \leq 0.05$.

\section{RESULTS AND DISCUSSION}

The BG level in the animals under LL conditions tended to increase by $13 \%$ from baseline over a 2 -week period starting on the 4 th day of the experiments. Melatonin insertion reduced (but not normalized as under DD and LD conditions) this level 1.8 times compared with DM animals, indicating its hypoglycemic action in LL conditions is less pronounced. The prevalence of diabetes has exponentially increased in recent decades due to such factors as nocturnal lifestyle and ageing, both of which influence the amount of melatonin produced in the pineal gland [8].

Under all types of illumination the activity of $\mathrm{LDH}$ (figure d) increases on average by $61 \%$ in the muscles of alloxan diabetic rats with DM compared with the control value, whereas the GC, the activity of PK and G6PD decreased on average by 37,53 and $40 \%$ respectively (figure $\mathrm{b}, \mathrm{c}, \mathrm{a})$. It is well known that muscle tissue is dependent on the presence of insulin.

It is well known, that muscle tissue is dependent on the presence of insulin.

In the absence of insulin glucose cannot even enter muscle cells. In the conditions of low glucose influx to muscles there is no substrate for glycolysis, hexose monophosphate shunt and glycogenesis. That's why the activities of PK and G6PD are decreased and content of glycogen falls. Earlier we showed [9] that pinealectomy, similar to the pineal gland hypofunction caused by permanent lighting, leads to a decrease in melatonin synthesis and secretion, which cause insulin resistance and reduce the gene expression of glucose transporter GLUT 4, 2, 1. It is logical that the activity of G6PD is reduced under LL conditions during DM, while an administration of melatonin increases its activity, probably due to direct activation [10].

The level of BG in the IGT rats under all types of illumination didn't reliably differ from the indices of intact rats. However, the activities of G6PD (Figure a) and LDH (Figure d) were, on average, higher by 49 and $24 \%$ respectively than in the control groups. The GC (Figure b) and the activity of PK (Figure c) in muscles of the IGT rats show tendency to decrease by an average of $12 \%$ from control under different light conditions, except in rats with IGT under LL conditions whose indices of G6PD (Figure a) were lower by $48 \%$ than those in the control group. The injection of melatonin in a dose of 10 $\mathrm{mg} / \mathrm{kg}$ was conducive to a normalization of the indices of carbohydrate metabolism in the group of animals with IGT in different light conditions. Additionally [11], exposure to light at night and ageing, both of which lower endogenous melatonin levels, may contribute to the incidence and/ or development of diabetes.

A 14-day injection of the same dose of melatonin to the DM rats contributed to a normalization of the BG level, the GC (Figure b), the activities of PK (Figure c) and LDH (Figure d) as well as to a considerable increase of the G6PD activity (Figure a) whose level exceeded the control value by an average of $32 \%$. Under the influence of melatonin, the increased G6PD activity may be due to an increased amount of substrate for G6PD (stimulating flow of glucose into cells and its phosphorilation) and direct action [12].

Oxidative stress plays a pivotal role in the development of diabetes complications, both microvascular and cardiovascular [13]. Melatonin, a potent antioxidant agent, is essential for glucose homeostasis and regulation [14]. It was determined [15] that melatonin supplementation influences oxidative stress parameters in elderly NIDDM patients.

Moreover, earlier [16, 17] we investigated Langergans islends in diabetic rats and recorded 

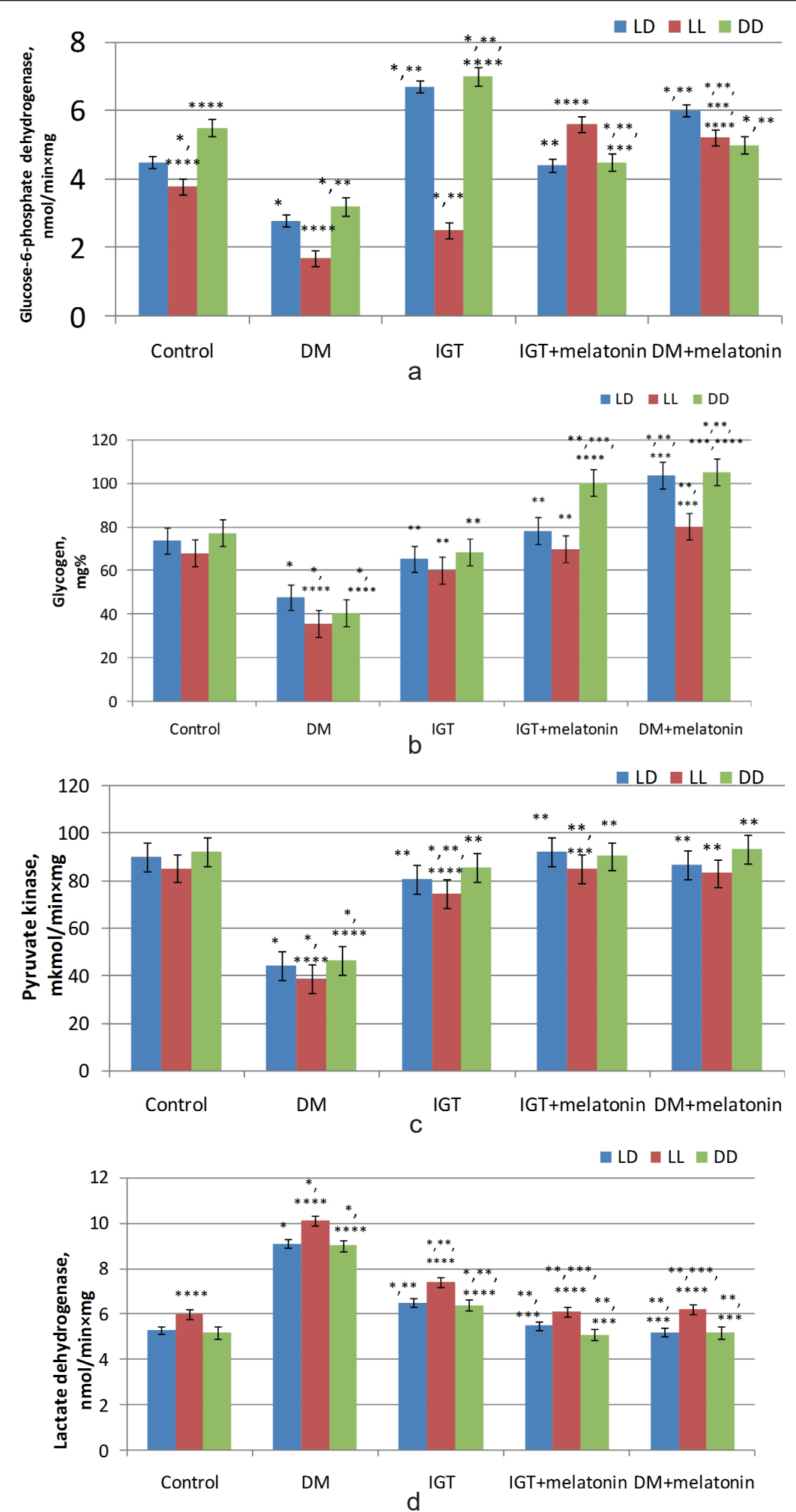

Figure. Changes in carbohydrates metabolism in muscles of rats, $(\mathrm{n}=6, \mathrm{x} \pm \mathrm{Sx}): 1 . * *^{*}, * * *, * * *$ - changes are reliable $(\mathrm{P} \leq 0.05) .2 . *$ - concerning control; $* *$ - concerning rats with $\mathrm{DM} ; * * *-$ concerning rats with IGT; $* * * *$ - concerning the values of control animals in the conditions of natural (artificial) equinox $-\mathrm{LD}$ 
histomorphological alterations: their pancreatic share reliably decreased by $55 \%$, number and percentage of beta-cells with necrosis decreased by 90 and $97 \%$ respectively compared with the control. Melatonin treatment caused a sharp decrease in the elevated serum glucose and partial regeneration/proliferation of beta-cells. It was concluded that the hypoglycemic action of melatonin could be partly due to amelioration in beta-cells of pancreatic islets.

Melatonin stimulates glucose transport to skeletal muscle cells via insulin receptor substrate-1/phosphoinositide-3-kinase pathway, which implies, at the molecular level, its role in glucose homeostasis and possibly in diabetes. Endogenous melatonin level may contribute to the incidence and/or development of diabetes. A strong phosphorilation of inositol-requiring enzyme 1 (IRE-1), c-JUN NH2-terminal kinase (JNK) and insulin receptor substrate 1 (IRS-1) serine as well as a dramatic decrease of IRS-1 tyrosine phosphorilation were observed in the presence of tunicamycin. All of these lead to a blockage of insulin signaling in skeletal muscle cells, which is reversed by a melatonin pretreatment. Also, melatonin may increase a plasma concentration of leptin in mice [18] and there are findings [19] that terminally ill insulin-deficient rodents with uncontrolled diabetes due to autoimmune or chemical destruction of beta-cells were made hyperleptinemic by an adenoviral transfer of the leptin gene. Within approximately 10 days their severe hyperglycemia and ketosis were corrected. Despite the lack of insulin, moribund animals resumed linear growth and appeared normal. Normoglycemia persisted 10-80 days without other treatment while normal physiological conditions lasted for approximately 175 days despite reappearance of moderate hyperglycemia. Inhibition of gluconeogenesis by suppression of hyperglucagonemia and reduction of hepatic cAMP response element-binding protein, phoshoenolpyruvate carboxykinase and peroxisome proliferator-activated receptor-gammacoactivator-1 alpha may explain the anticatabolic effect. Up-regulation of insulin-like growth factor 1 (IGF-1) expression, plasma levels and increasing IGF-1 receptor phosphorilation in muscles may explain the increased insulin receptor substrate 1, PI3K and ERK phosphorilation in skeletal muscles. These findings suggest that leptin reverses the catabolic consequences of a total lack of insulin, potentially by suppressing glucagon action on the liver and enhancing the insulinomimetic actions of IGF-1 on skeletal muscle, and suggest strategies for making type 1 diabetes insulin-independent.

Here, it has been ascertained that alloxan monohydrate administration results in a significant elevation of the blood basal glycemia level and an increase of the activities of lactate dehydrogenase. However, a decrease of the GC and the G6PD activity in muscular tissue were directly dependent on the presence of hyperglycemia.

Thus, under all the light conditions we observed marked inhibition of glycolysis (reduced PK activity), glycogen synthesis (reduced glycogen content), probable lactate accumulation (increased LDH activity) and inhibition, except in two subgroups, of oxidative stage of Pentose Phosphate Pathway of glucose-6-phosphate oxidation (reduced G6PD activity) in muscular tissue of alloxan diabetic animals. Our main finding is an increasing of the G6PD activity under LL and DD conditions in animals with IGT.

The established changes in the activities of glucose-6-phosphate dehydrogenase and lactate dehydrogenase in animals with alloxan diabetes turned out to be more marked under the conditions of permanent light than with equinox or permanent darkness. A 14-day introduction of melatonin leads to a marked improvement of the state of carbohydrate metabolism in muscular tissue accompanied by a normalization of the indices under study.

The authors of this study confirm that the research and publication of the results were not associated with any conflicts regarding commercial or financial relations, relations with organizations and/or individuals who may have been related to 
the study, and interrelations of coauthors of the article.

\section{И.М. Яремий, А.Ю. Кушнир, В.И. Швец, И.Р. Янчий, Н.В. Швец}

\section{ВЛИЯНИЕ МЕЛАТОНИНА НА УГЛЕВОД- НЫЙ ОБМЕН В МЫШЦАХ КРЫС С АЛЛОК- САНОВЫМ ДИАБЕТОМ}

Изучали влияние мелатонина на базальное содержание глюкозы в крови, гликогена, активность глюкозо-6-фосфатдегидрогеназы (ГбФД), пируваткиназы и лактатдегидрогеназы (ЛДГ) в мышцах крыс с алоксаниндуцированым диабетом в условиях разного фотопериода. Следует отметить рост активности ЛДГ на $61 \%$, тогда как содержание гликогена и активности пируваткиназы и ГбФД уменьшились на 37, 53 и 40\% соответственно по сравнению с контрольными значениями. Все эти изменения не зависели от условий освещения. Базальное содержание глюкозы у крыс с нарушенной толерантностью к ней не достоверно отличалось от контроля, однако активность ЛДГ и ГбФД были выше на 24 и 49\% соответственно, за исключением крыс, находившихся в условиях постоянного освещения, активность ГбФД которых была ниже на $48 \%$. Введение мелатонина (14 ежедневных инъекций в дозе 10 мг/кг) приводило к улучшению метаболизма углеводов: содержание глюкозы, гликогена, активность пируваткиназы и ЛДГ нормализовались, а активность ГбФД увеличивалась в среднем на $32 \%$. Влияние мелатонина было более выраженное у крыс с нарушенной толерантностью к глюкозе в условиях постоянного освещения.

Ключевые слова: мелатонин; аллоксановый диабет; углеводный обмен; мышцы; крысы.

\section{І. М. Яремій, О.Ю. Кушнір, В.І. Швець, I.P. Янчій ${ }^{1}$, Н.В. Швець \\ ВПЛИВ МЕЛАТОНІНУ НА ОБМІН ВУГЛЕ- ВОДІВ У М'ЯЗАХ ЩУРІВ 3 АЛОКСАНОВИМ ДІАБЕТОМ}

Вивчали вплив мелатоніну на базальний вміст глюкози в крові, глікогену, активність глюкозо-6-фосфатдегідрогенази (Г6ФД), піруваткінази і лактатдегідрогенази (ЛДГ) у м'язах щурів $з$ алоксаніндукованим діабетом в умовах різного фотоперіоду. Слід відмітити зростання активності ЛДГ на $61 \%$, тоді як вміст глікогену та активність піруваткінази та ГбФД зменшилися на 37, 53 та 40\% відповідно порівняно 3 контрольними значеннями. Всі ці зміни не залежали від умов освітлення. Базальний вміст глюкози у щурів з порушеною толерантністю до неї відрізнявся не достовірно від контролю, проте активність ЛДГ та ГбФД були вищими на 24 та 49\% відповідно, за винятком щурів, які перебували в умовах постійного освітлення, активність ГбФД яких була нижчою на 48\%. Введення мелатоніну
(14 щоденних ін'єкцій в дозі 10 мг/кг) призводило до поліпшення метаболізму вуглеводів: вміст глюкози, глікогену, активність піруваткінази та ЛДГ нормалізувалися, а активність ГбФД збільшувалася в середньому на $32 \%$. Вплив мелатоніну був помітним у щурів 3 порушеною толерантністю до глюкози за умов постійного освітлення. Ключові слова: мелатонін; алоксановий діабет; вуглеводний обмін; м'язи; щури.

Вищий державний навчальний заклад Украйни «Буковинський державний медичний університет», Чернівці;

${ }^{1}$ ДУ Інститут ендокринологї та обміну речовин ім. В.П.Комісаренка НАМН України, Київ;

e-mail:kushnir@bsmu.edu.ua

\section{REFERENCES}

1. Nabavi SF, Habtemariam S, Daglia M, Sureda A, SobarzoSánchez E, Selamoglu Z, Gulhan MF, Nabavi SM. Melatonin and respiratory diseases: a review. Curr Top Med Chem. 2017;17(4):467-88.

2. Thomas AP, Hoang J, Vongbunyong K, Nguyen A, Rakshit K, Matveyenko AV. Administration of melatonin and metformin prevents deleterious effects of circadian disruption and obesity in male rats. Endocrinology. 2016;157(12):4720-31.

3. Qian J, Block GD, Colwell CS, Matveyenko AV. Consequences of exposure to light at night on the pancreatic islet circadian clock and function in rats. Diabetes. 2013;62(10):3469-78.

4. Marcheva B, Ramsey KM, Buhr ED, Kobayashi Y, Su H, Ko CH, Ivanova G, Omura C, Mo S, Vitaterna MH, Lopez JP, Philipson LH, Bradfield CA, Crosby SD, JeBailey L, Wang X, Takahashi JS, Bass J. Disruption of the clock components CLOCK and BMAL1 leads to hypoinsulinaemia and diabetes. Nature. 2010;466(7306):627-31.

5. Krishna T, Yaremii I, Kushnir O. Protective effects of melatonin in alloxan diabetic rats under conditions of constant darkness. Book of abstracts of 24-th European Students' Conference ["Exploring the unknown"]. 2013; ESCID 396.

6. Favero G, Rodella LF, Nardo L, Giugno L, Cocchi MA, Borsani E, Reiter RJ, Rezzani R. A comparison of melatonin and $\alpha$-lipoic acid in the induction of antioxidant defenses in L6 rat skeletal muscle cells. Age (Dordr). 2015;37(4):9824.

7. Kushnir OYu, Yaremii IM, Shvetsv VI, Shvets NV. Influence of melatonin on carbohydrate metabolism in the kidney of alloxan diabetic rats. Fiziol. Zh., 2017;63(4):6471. [Ukrainian].

8. Ha E, Yim SV, Chung JH, Yoon KS, Kang I, Cho YH, Baik HH. Melatonin stimulates glucose transport via insulin receptor substrate-1/phosphatidylinositol 3-kinase pathway in $\mathrm{C} 2 \mathrm{C} 12$ murine skeletal muscle cells. J Pineal Res. 2006;41(1):67-72.

9. Kushnir A., Yaremii I, Malinevskaya A. Impact of melatonin on the activity of pyruvate kinase in the liver of alloxan - 
diabetic and tetrachlormethane intoxicated rats exposed to light deprivation. Eur. Applied Sci. 2014;2:35-37.

10. Gesmundo I, Villanova T, Banfi D, Gamba G, Granata R. Role of Melatonin, Galanin, and RFamide Neuropeptides QRFP26 and QRFP43 in the Neuroendocrine Control of Pancreatic $\beta$-Cell Function. Front Endocrinol (Lausanne). 2017;8:143.

11. Lin GJ, Huang SH, Chen YW, Hueng DY, Chien MW, Chia WT, Chang DM, Sytwu HK. Melatonin prolongs islet graft survival in diabetic NOD mice. J Pineal Res. 2009 Oct;47(3):284-92.

12. Aly HF, Mantawy MM. Comparative effects of zinc, selenium and vitamin $\mathrm{E}$ or their combination on carbohydrate metabolizing enzymes and oxidative stress in streptozotocin induced-diabetic rats. Eur Rev Med Pharmacol Sci. 2012;16(1):66-78.

13. Gerush I, Boichuk T, Yaremii I, Kushnir O, Gerush O. Effects of melatonin on the glutathione system in the blood of alloxan diabetic rats. The International Union of Biochemistry and Molecular Biology (IUBMB) and the Federation of European Biochemical Societies (FEBS). 2012;279(1):88
14. Kushnir A., Meshchyshen I, Yaremii I. Hypoglycemic and antioxidant action of melatonin in alloxan diabetic rats. Annales Universitatis Marie Curie Skladovska. 2010;23(3,31):227-30.

15. Czuczejko J, Sielski Ł, Woźniak B, Woźniak A, SzewczykGolec K. Melatonin supplementation improves oxidative and inflammatory state in the blood of professional athletes during the preparatory period for competitions. Free Radical Res. 2019;53(2):198-209.

16. Brar J, Chhokar A. Kushnir. O. Influence of melatonin long term introduction on condition of the Langergans islets of the pancreas i alloxan diabetic rats. 22-nd Inter. Stud. Congress of biomedical sciences. Book of abstract. 2015; 544.

17. Kushnir A, Davydenko I. Influence of melatonin on condition of the langergans isles of the pancreas in alloksan diabetic rats. World Med and Biol. 2009;5(4):31-5.

18. Buonfiglio D, Parthimos R, Dantas R. Melatonin absence leads to long-term leptin resistance and overweight in rats front endocrinol (Lausanne). 2018;9:122.

19. Oberlin D and Buettner C. How does leptin restore euglycemia in insulin-deficient diabetes? J Clin Invest. 2017;127(2):450-53.

Received 18.03.2019 